\title{
The Relative Importance of Determinants of the Solar Photovoltaic Industry in China: Analyses by the Diamond Model and the Analytic Hierarchy Process
}

\author{
Tiantian Zhang ${ }^{1, *}$, Ken'ichi Matsumoto $^{2}$ (D) and Kei Nakagawa $^{3}(\mathbb{D}$ \\ 1 Graduate School of Fisheries and Environmental Sciences, Nagasaki University, 1-14 Bunkyo-machi, \\ Nagasaki 852-8521, Japan \\ 2 Faculty of Economics, Toyo University, 5-28-20 Hakusan, Bunkyo-ku, Tokyo 112-8606, Japan; \\ matsumoto1005@toyo.jp \\ 3 Institute of Integrated Science and Technology, Nagasaki University, 1-14 Bunkyo-machi, \\ Nagasaki 852-8521, Japan; kei-naka@nagasaki-u.ac.jp \\ * Correspondence: zhangtiantian0701@gmail.com
}

Citation: Zhang, T.; Matsumoto, K.; Nakagawa, K. The Relative Importance of Determinants of the Solar Photovoltaic Industry in China: Analyses by the Diamond Model and the Analytic Hierarchy Process. Energies 2021, 14, 6600. https:// doi.org/10.3390/en14206600

Academic Editor: Ignacio Mauleón

Received: 24 August 2021

Accepted: 8 October 2021

Published: 13 October 2021

Publisher's Note: MDPI stays neutral with regard to jurisdictional claims in published maps and institutional affiliations.

Copyright: () 2021 by the authors. Licensee MDPI, Basel, Switzerland. This article is an open access article distributed under the terms and conditions of the Creative Commons Attribution (CC BY) license (https:// creativecommons.org/licenses/by/ $4.0 /)$.

\begin{abstract}
Within China's renewable energy industry, the importance of the solar photovoltaic industry has been increasingly recognized. Many Chinese provinces have adopted various measures to develop the solar photovoltaic industry. This study used the diamond model and the analytic hierarchy process to clarify the relative importance of the determinants of the development of the solar photovoltaic industry. A total of 22 determinants in six categories (i.e., factor condition; demand condition; firm strategy, structure, and rivalry; related and support industries; government; and chance) were analyzed. The results show that besides factor condition, demand condition and firm strategy, structure, and rivalry have also had a strong influence on the development of China's photovoltaic industry. The findings also indicate that some traditional factors, such as labor costs and acquiring land, are very important to the development of the solar photovoltaic industry. The relative importance of the determinants clarified through this study provides a standard for the actions of policymakers and decision makers.
\end{abstract}

Keywords: photovoltaic industry; diamond model; analytic hierarchy process; determinants; relative importance; renewable energy

\section{Introduction}

Under the pressure of the rapidly increasing energy production capacity required to cope with the growing energy demand, deal with energy use challenges, and promote sustainable economic development, many provinces in China are increasingly fostering sustainable energy development. Although solar photovoltaics account for a small portion of the renewable energy flow, the Chinese government is currently paying attention to its economic potential. For example, as of July 2021, various provinces have announced their energy plan targets during the 14th Five-Year Plan (2021-2025) and 16 provinces have clearly announced a newly increased scale of photovoltaic plans during this period (see Supplementary Material Table S1). This indicates that the Chinese government is increasingly aware of the importance of the effective development of the solar photovoltaic industry in solving the energy supply shortage among provinces [1]. The solar photovoltaic sector includes silicon mining, crystalline silicon purification, manufacturing technology, wafer cutting, battery production, module installation, and power generation. For many local governments, solar photovoltaics are an essential energy source and a valuable channel for transferring more productive and innovative technologies. In the process of transitioning to a global clean energy system, the Chinese government has been vigorously promoting the development of photovoltaic power generation and creating a favorable environment for the renewable energy industry, especially the solar photovoltaic industry. 
Renewable energy has attracted most of the world's attention, which will significantly promote market competition and a safe and efficient electricity market transition [2]. To this end, understanding the determinants of competitiveness in the Chinese photovoltaic industry and clarifying the relative importance of these determinants will provide a standard for policymakers to prioritize policies and actions.

The scale of China's photovoltaic industry is growing, and practitioners within this industry are interested in the effectiveness of various factors that aim to make this sector attractive. However, studies that clarify the relative importance of the determinants of the photovoltaic industry's competitiveness are still limited.

Most previous studies have used the diamond model method to find important determinants. For example, Tsai et al. [3] assessed the competitiveness of Taiwan's solar photovoltaic industry based on six dimensions of the diamond model (i.e., firm strategy; government, structure, and rivalry; demand condition; chance; factor condition; and related and support industries). Luo et al. [4] assessed the photovoltaic industry and its influencing factors using the diamond model. Zhao et al. [5] constructed a system dynamics model to analyze the impact of research and development investment on China's photovoltaic power generation industry. Shao et al. [6] used a spatial econometric model to assess the performance of government subsidies and evaluate the photovoltaic industry based on the spatial dependence among regions. $\mathrm{Xu}$ et al. [7] constructed an energy-economy-environment integrated model to explore China's solar photovoltaic power optimal development path from 2018 to 2050. Dögl et al. [8] used modified versions of the diamond model and applied them to technical analysis of the renewable energy industry in countries such as Germany, India, and China to help policymakers provide environmental support and standards of action. Fang et al. [9] conducted a quantitative analysis of the competitiveness of the renewable energy industry in countries such as the Group of Twenty using the modified diamond model, which revealed the driving forces of the renewable energy industry and provided a policy analysis framework for policymakers based on each country's resources and competitive advantages. $\mathrm{Li}$ [10] used the six elements of the diamond model to analyze the impact of each factor on the competitiveness of China's photovoltaic industry. Long [11] analyzed the existing problems of China's solar photovoltaic industry using the diamond model as well as qualitative and quantitative methods from the industrial chain, market, trade, policy, and other aspects. Jing [12] conducted a diamond model comparison analysis of China, the United States, Germany, Japan, and four other countries, identifying the competitiveness gap in the solar photovoltaic industry's international trade and providing suggestions for the development of China's solar photovoltaic industry. In addition, the modified diamond model was used to analyze the influence of the international market share of China's photovoltaic industry, the revealed competitiveness index, and the trade specialization index [13]. The results show that China's photovoltaic industry is overly dependent on the international market and the domestic photovoltaic market requires further development [13]. Based on the diamond model's four significant factors, Chen [14] analyzed the policy and corporate strategic factors of international competitiveness and revealed two categories of main factors, macro-environmental and microeconomic, affecting the international competitiveness of the photovoltaic industry. As an improved version of the diamond model, the gear model was used to critically analyze the significant determinants of the photovoltaic power industry's competitiveness in China [15]. The results emphasize establishing a complete photovoltaic power generation industry chain and improving independent innovation, government policies, financial incentives, and other measures. Although these studies provide crucial empirical evidence, they also have a limitation. Most of them show the policy's influence as a determinant of the photovoltaic industry, which ignores the relative priorities of other determinants in the photovoltaic industry chain. Thus, research on the relative importance of different influencing factors in the competitiveness of the photovoltaic industry is clearly lacking. This limitation is mainly due to the unavailability of data. In addition, many provinces have implemented multiple 
support policies in parallel, which makes it difficult to assess the relative importance of each factor.

Painuly [16] emphasized that interaction with experts in the field through structured interviews or questionnaires is critical to identify the relative importance of favorable factors because stakeholders' awareness of barriers may reveal shortcomings in existing policies and help identify measures to overcome them. This shows the relative importance of expert opinions in determining the missing factors in previous studies and clarifying the determinants of the competitiveness of the photovoltaic industry in China. Therefore, to overcome the abovementioned limitation and to verify and supplement the diamond model research, this study conducted a questionnaire survey based on the diamond model and analytic hierarchy process (AHP) to determine the relative importance of factors affecting China's solar photovoltaic industry. The relevant literature on China's photovoltaic industry shows that most studies have used the diamond model to analyze the development of this industry based on six different factors. However, few studies have used the AHP to detect the proportion of these six factors [17]. This study clarifies the relative importance of the determinants using the AHP, which is an originality of this work.

This study is the first attempt to explain the relative importance of the determinants of the Chinese photovoltaic industry's competitiveness using the diamond model and the AHP. An analysis of the industry can be used to indirectly predict the economic development of a country or a region.

The rest of the paper is structured as follows. The second section introduces the method adopted in this study. The third section presents the determinants of the Chinese photovoltaic industry's competitiveness. Section 4 provides the results and clarifies the relative importance of the determinants. Based on the results, Section 5 presents a discussion. Finally, Section 6 presents the conclusions.

\section{Methods}

The method used in this study is the diamond model [18] (Porter's diamond model theory (Michael Porter diamond model)) and the AHP. These tools are explained separately in the sections below.

\subsection{The Diamond Model}

There are many research methods for investigating solar photovoltaic industrial competitiveness. The diamond model is an effective method for analyzing the competitive advantage of the industry. According to the literature, several studies have used this model to analyze many factors of competitive industrial advantage [19-22].

The diamond model consists of six parts: factor condition; demand condition; related and support industries; firm strategy, structure, and rivalry; government; and chance. The six parts are introduced below.

- Factor condition: This refers to the status of the country in terms of production factors, such as labor, infrastructure, and natural resources [18]. In essence, these resources are the cornerstone of value creation and production activities.

- Demand condition: This connotes the nature of the home market demand for the industry's product or service [18]. Porter [18] stated that when the domestic demand condition is relatively complex and there are overall expectations for high-quality goods and services, domestic companies are more likely to respond by increasing their production capacity.

- Related and support industries: This is the existence or absence of a supply industry in a country that can support the competitiveness of an industry in the global market [23]. New competitive industries will always be created in related and support industries, and opportunities for information and technology exchange will be provided. The relationship between these industrial clusters is critical to the success of a certain sector within a country [24]. 
- Firm strategy, structure, and rivalry: Porter believed that corporate strategy, industrial structure, and competition all have an impact on industrial competitiveness [18]. The strategy, structure, and competition of enterprises have mastered the intensity of domestic competition. Whether a sector is extremely competitive at home will affect the increase in productivity required for international competition [24].

- Government: The government's position in competition has a great effect because it is directly responsible for improving the well-being of citizens and companies [25].

- Chance: Porter considered accidental events to be things that have nothing to do with the national situation [18]. Opportunistic events are usually improvements beyond the company's control. Such incidents avoid the advantages of previously constituted competitors and create the potential for new national companies to replace them [24].

Based on the six aspects of the diamond model, we constructed an analysis framework for the competitiveness of China's solar photovoltaic industry. The specific analysis indicators are shown in Table 1. The range of the six parts of the diamond model in the photovoltaic industry is outlined in the table. In the third section, we further refine the impact factors of these six parts.

Table 1. Theoretical framework of the diamond model to evaluate the competitiveness of China's photovoltaic industry.

\begin{tabular}{|c|c|c|c|}
\hline Factors & Main Method Used in the Literature & Supporting Indicators & Source \\
\hline Factor condition & $\begin{array}{l}\text { The diamond model; a revised diamond model; } \\
\text { the diamond model and the revealed competitive } \\
\text { comparative advantage index, trade specialization } \\
\text { index analysis, and the international market share; } \\
\text { the diamond model and the Granger causality } \\
\text { test; the diamond model and the gear model }\end{array}$ & $\begin{array}{l}\text { Natural resources, scientists, } \\
\text { infrastructure, labor cost }\end{array}$ & [8-15] \\
\hline Demand condition & $\begin{array}{l}\text { The diamond model; a revised diamond model; } \\
\text { the diamond model and the revealed competitive } \\
\text { comparative advantage index, trade specialization } \\
\text { index analysis, and the international market share; } \\
\text { the diamond model and the Granger causality } \\
\text { test; the diamond model and the gear model }\end{array}$ & Market size, installed capacity & {$[8-11,13-15]$} \\
\hline Related and support industries & $\begin{array}{l}\text { The diamond model; a revised diamond model; } \\
\text { the diamond model and the revealed competitive } \\
\text { comparative advantage index, trade specialization } \\
\text { index analysis, and the international market share; } \\
\text { the diamond model and the Granger causality } \\
\text { test; the diamond model and the gear model }\end{array}$ & $\begin{array}{l}\text { Photovoltaic manufacturing, grid } \\
\text { construction, supporting firms }\end{array}$ & {$[8-11,13-15]$} \\
\hline Firm strategy, structure, and rivalry & $\begin{array}{l}\text { The diamond model; a revised diamond model; } \\
\text { the diamond model and the revealed competitive } \\
\text { comparative advantage index, trade specialization } \\
\text { index analysis, and the international market share; } \\
\text { the diamond model and the gear model }\end{array}$ & $\begin{array}{l}\text { Industry rules, industry competition, } \\
\text { industry environment }\end{array}$ & {$[8-10,13-15]$} \\
\hline Government & $\begin{array}{l}\text { A revised diamond model; the diamond model } \\
\text { and the revealed competitive comparative } \\
\text { advantage index, trade specialization index } \\
\text { analysis, and the international market share; the } \\
\text { diamond model and the gear model }\end{array}$ & Government support & {$[8-10,13-15]$} \\
\hline Chance & $\begin{array}{l}\text { The diamond model and the revealed competitive } \\
\text { comparative advantage index, trade specialization } \\
\text { index analysis, and the international market share; } \\
\text { the diamond model and the gear model }\end{array}$ & Industry challenges & {$[10,13,15]$} \\
\hline
\end{tabular}

To clarify the relative importance of each aspect in the analysis framework, we conducted a questionnaire survey with experts in the Chinese solar photovoltaic industry (see Supplementary Material Figure S1) and then used the AHP to analyze the relativity of each determinant to finally determine the priority.

\subsection{The Analytic Hierarchy Process (AHP)}

The AHP is an important tool for decision making and determining a set of standards and sub-standards and other multi-standard problems. The AHP was developed by Saaty [26]. Sipahi et al. [27] emphasized the importance of the AHP, indicating its suitability for complex social problems that cannot separate intangible and tangible factors. The AHP has been applied in many fields, including studies related to renewable energy [28-32]. However, a small number of studies have used a combination of the diamond model and 
the AHP to test the relative importance of the determinants of the competitiveness of the solar photovoltaic industry.

First, the determinants or influencing factors determined in the diamond model were brought into the AHP to construct the category parameters in the hierarchical model. In this study, the relative importance of the determinants of the competitiveness of the photovoltaic industry in China was at the top of the hierarchy and broad categories and subcategories were placed below it. The experts then used the 1-9 scale proposed by Saaty [26] to compare the factors with each other and their influence on the abovementioned six factors (factor condition; demand condition; related and support industries; firm strategy, structure, and rivalry; government; and chance) in the hierarchical structure. The 1-9 scale is explained in more detail in Table 2. This process systematically transforms pairwise judgments into pairwise matrices.

Table 2. Analytic hierarchy measurement scale [26].

\begin{tabular}{|c|c|c|}
\hline Intensity of Importance & Definition & Explanation \\
\hline 1 & Equal importance & Two activities contribute equally to the objective. \\
\hline 3 & Moderate importance & Experience and judgment slightly favor one activity over another. \\
\hline 5 & Strong importance & Experience and judgment strongly favor one activity over another. \\
\hline 7 & Very strong or demonstrated importance & An activity is favored very strongly over another, indicating its dominance. \\
\hline 9 & Extreme importance & The evidence favoring one activity over another is of the highest possible order. \\
\hline $2,4,6,8$ & For compromise between the above values & Sometimes, one needs to interpolate a compromise judgment numerically. \\
\hline
\end{tabular}

A factor was divided by the sum of the column formulas of the factors to obtain the normalized matrix, and then the eigenvector was calculated by averaging the factors in the row. The value of each factor represents the weight of importance. In this study, the average value of the experts' evaluation was expressed as the relative importance of each factor.

Next, the consistency of each pairwise comparison matrix was checked to prove that the experts' evaluations are correct, using the common measures of consistency index $(C I)$ and consistency ratio $(C R)$ [30-33].

CI was calculated according to Equation (1) [26]:

$$
C I=\frac{\lambda_{\max }-n}{n-1}
$$

where $n$ is the number of evaluation factors and $\lambda_{\max }$ is the maximum eigenvalue of the matrix.

$C R$ is defined as follows:

$$
C R=\frac{C I}{R I}
$$

where $R I$ is the average value of $C I$ obtained from 500 pairs of positive-equivalent comparison matrices, which are randomly generated using a 1-9 scale [26].

$R I$ values of different matrix orders are shown in Table 3.

Table 3. $R I$ values for different $n$ [26].

\begin{tabular}{cc}
\hline $\boldsymbol{n}$ & RI \\
\hline $1-2$ & 0 \\
3 & 0.58 \\
4 & 0.90 \\
5 & 1.12 \\
6 & 1.24 \\
7 & 1.32 \\
\hline
\end{tabular}

If the $C R$ is 0 , then the respondents' answers are completely consistent; if the $C R$ equals 1 , then the answers are completely inconsistent. In general, based on Saaty's suggestion, answers within the range of $0.1-0.15$ were acceptable [26]. Based on the steps proposed by Goepel [34], we combined all the pairwise comparisons that met a $C R$ criterion into a decision matrix $C_{i j}$ by using the eigenvector method and the decision matrix $C_{i j}$ combining $m$ participants' inputs to obtain the group result [34]. The weighted geometric mean of the 
decision matrix factors and the pairwise $M \times M$ comparison matrix $A$ were used with each expert's weight. The calculation steps are as shown below.

$$
C_{i j}=\exp \frac{\sum_{k=1}^{m} \omega_{k} \ln A}{\sum_{k=1}^{m} \omega_{k}}
$$

where $k$ is participants, $\omega_{k}$ is each expert's weight, and $A=a_{i j(k)}$.

Through Equation (3), we can calculate the relative importance of each factor, which can be compared with one another.

Then, we can calculate the experts' consensus rate by using the Shannon alpha, beta, and gamma entropy [34]. The consensus rate indicator ranges from 0 (no consensus among experts) to 1 (complete consensus among experts).

The consensus rate $S$ is calculated by Equation (4):

$$
S=\left(1 / D_{\beta}-D_{\alpha \min } / D_{\gamma \max }\right) /\left(1-D_{\alpha \min } / D_{\gamma \max }\right)
$$

where $D_{\alpha}$ is the average individual decision maker's priority distribution among criteria. $D_{\beta}$ is a measure of variations of priority distributions among decision makers within the group. $D_{\gamma}$ is the gamma diversity of order 1 [34].

The true diversity of order $1 D$ is given by

$$
D=\exp (H)
$$

where the Shannon entropy $H[34]$ can be written as

$$
H=-\sum_{i=1}^{m} \rho_{i} \ln \rho_{i}
$$

where $\rho_{i}$ is the priorities for criteria $i=1$ to $m$.

The Shannon beta entropy $H_{\beta}$ can be calculated as follows:

$$
H_{\beta}=H_{\gamma}-H_{\alpha}
$$

where $H_{\gamma}$ is the Shannon gamma entropy and $H_{\alpha}$ is the Shannon alpha entropy for the priorities of $k$ respondents.

The consensus rate can be calculated for each category and subcategory by these equations.

We used the AHP Excel template [35] to calculate the relative importance of each factor and the consensus rate between the respondents (experts).

In this study, questionnaires were sent to experts in decision-making positions of Chinese companies in the solar photovoltaic industry. These companies are mainly located in Southwest China, Beijing-Tianjin-Hebei, Yangtze River Delta, Pearl River Delta, and Northwest China. The questionnaires were distributed to 24 experts from 12 May to 30 June, 2021. The authors directly contacted these experts by telephone, and 24 questionnaires were returned ( $100 \%$ response rate). In each questionnaire, the experts were also asked for their opinions and suggestions on improving China's photovoltaic industry, some of which are shared in Section 5.3. Based on the results of the 24 questionnaires, their $C R$ values were calculated separately. Of these 24 experts, four were not qualified because their $C R$ values were greater than 0.15 (Table 4 ). 
Table 4. Consistency ratio of each category for each respondent.

\begin{tabular}{|c|c|c|c|c|c|c|c|}
\hline Respondent & Categories & $\begin{array}{c}\text { Factor } \\
\text { Condition }\end{array}$ & $\begin{array}{l}\text { Demand } \\
\text { Condition }\end{array}$ & $\begin{array}{c}\text { Firm Strategy, } \\
\text { Structure, and Rivalry }\end{array}$ & $\begin{array}{c}\text { Related and } \\
\text { Support Industries }\end{array}$ & Government & Chance \\
\hline No. 1 & 0.13 & 0.11 & 0.10 & 0.01 & 0.06 & 0.09 & 0.00 \\
\hline No. 2 & 0.10 & 0.14 & 0.07 & 0.02 & 0.08 & 0.07 & 0.00 \\
\hline No. 3 & 0.14 & 0.11 & 0.11 & 0.08 & 0.09 & 0.04 & 0.00 \\
\hline No. 4 & 0.14 & 0.14 & 0.08 & 0.06 & 0.01 & 0.12 & 0.00 \\
\hline No. 5 & 0.14 & 0.12 & 0.10 & 0.08 & 0.06 & 0.12 & 0.00 \\
\hline No. 6 & 0.14 & 0.14 & 0.04 & 0.09 & 0.02 & 0.09 & 0.00 \\
\hline No. 7 & 0.13 & 0.13 & 0.09 & 0.06 & 0.01 & 0.12 & 0.00 \\
\hline No. 8 & 0.11 & 0.14 & 0.10 & 0.02 & 0.04 & 0.08 & 0.00 \\
\hline No. 9 & 0.07 & 0.13 & 0.07 & 0.06 & 0.06 & 0.13 & 0.00 \\
\hline No. 10 & 0.13 & 0.11 & 0.03 & 0.02 & 0.06 & 0.14 & 0.00 \\
\hline No. 11 & 0.14 & 0.12 & 0.06 & 0.14 & 0.06 & 0.11 & 0.00 \\
\hline No. 12 & 0.10 & 0.14 & 0.03 & 0.06 & 0.02 & 0.11 & 0.00 \\
\hline No. 13 & 0.13 & 0.14 & 0.12 & 0.10 & 0.06 & 0.11 & 0.00 \\
\hline No. 14 & 0.13 & 0.13 & 0.07 & 0.08 & 0.06 & 0.09 & 0.00 \\
\hline No. 15 & 0.13 & 0.13 & 0.07 & 0.01 & 0.08 & 0.12 & 0.00 \\
\hline No. 16 & 0.11 & 0.14 & 0.12 & 0.06 & 0.04 & 0.11 & 0.00 \\
\hline No. 17 & 0.08 & 0.10 & 0.07 & 0.06 & 0.01 & 0.04 & 0.00 \\
\hline No. 18 & 0.13 & 0.13 & 0.09 & 0.06 & 0.02 & 0.07 & 0.00 \\
\hline No. 19 & 0.14 & 0.13 & 0.05 & 0.06 & 0.10 & 0.05 & 0.00 \\
\hline No. 20 & 0.13 & 0.14 & 0.08 & 0.02 & 0.06 & 0.10 & 0.00 \\
\hline No. 21 & 0.16 & 0.21 & 0.32 & 0.14 & 0.06 & 0.14 & 0.00 \\
\hline No. 22 & 0.22 & 0.22 & 0.01 & 0.00 & 0.09 & 0.09 & 0.00 \\
\hline No. 23 & 0.17 & 0.23 & 0.01 & 0.00 & 0.08 & 0.08 & 0.00 \\
\hline No. 24 & 0.16 & 0.33 & 0.17 & 0.14 & 0.06 & 0.13 & 0.00 \\
\hline
\end{tabular}

\section{Identifying the Subcategories (Determinants) Based on the Six Elements of the Diamond Model}

\subsection{Overview}

Many factors affect China's photovoltaic industry. These include subsidies for solar technology research and development, incentive policies for purchasing photovoltaic systems, photovoltaic industry policies, photovoltaic enterprise strategies, and operations. We conducted a detailed literature review of the determinants of the solar photovoltaic industry's competitiveness in China.

Based on the theoretical framework (Table 1) and the literature review, 22 subcategories (determinants) were identified (Table 5). The following table briefly introduces the definitions of the determinants in each category used in the AHP in this study.

Table 5. Summary of the classification of determinants.

\begin{tabular}{cc}
\hline Category & Subcategories (Determinants) \\
\hline & F1 natural resources \\
Factor condition & F2 mineral resources reserves \\
& F3 labor cost \\
& F4 scientific research and technology \\
F5 acquiring land
\end{tabular}

F6 energy supply gap (environmental pressure)

Demand condition

F7 newly installed capacity for solar photovoltaic power generation (market scale)

F8 photovoltaic power consumption capacity (local acceptance)

F9 export volume of photovoltaic products (foreign demand status)

\begin{tabular}{ccc}
\hline Firm strategy, structure, and rivalry & $\begin{array}{c}\text { F10 reasonable and effective development plans for photovoltaic power generation enterprises (a reasonably } \\
\text { structured renewable energy development plan) } \\
\text { F11 interest rate risk } \\
\text { Related and support industries }\end{array}$ & $\begin{array}{c}\text { F13 photovoltaic equipment manufacturing } \\
\text { F14 photovoltaic power station } \\
\text { F15 tax incentives }\end{array}$ \\
\hline Government & $\begin{array}{c}\text { F16 policies issued by local governments (policy regulations, local government strategies) } \\
\text { F17 tax reduction and exemption (exemption of customs duties and import value-added tax) } \\
\text { F18 financial subsidy intensity } \\
\text { F19 China's central government photovoltaic power generation target } \\
\text { F20 feed-in tariff }\end{array}$ \\
\hline Chance & $\begin{array}{c}\text { F21 opportunities brought by the 531 Photovoltaic New Deal } \\
\text { F22 prospects of the photovoltaic industry (low-carbon economy, clean energy) }\end{array}$
\end{tabular}




\subsection{Factor Condition}

The factor condition includes natural resources, mineral resource reserves, labor costs, scientific research and technology, and acquiring land.

- Natural resources (F1): This refers to the amount of natural resources present in the area. In this study, the term refers to the duration and period of solar radiation $[36,37]$.

- Mineral resource reserves (F2): This refers to the resource potential of silicon, which is one of the most important raw materials for the photovoltaic industry [38].

- Labor cost (F3): This refers to the labor cost of installing, operating, and maintaining solar photovoltaic power generation [39].

- Scientific research and technology (F4): Scientific research and technology are one of the key factors in the development of photovoltaic power generation projects $[39,40]$.

- Acquiring land (F5): Acquiring land indicates how easy it is to obtain the land required for the development of solar photovoltaic projects [41,42].

\subsection{Demand Condition}

The demand condition includes the energy supply gap, the newly installed capacity for solar photovoltaic power generation, the photovoltaic power consumption capacity, and the export volume of photovoltaic products.

- $\quad$ Energy supply gap (F6): Conventional power cannot meet the growing power demand. This demand stimulates the rapid development of photovoltaic power generation [43-45].

- Newly installed capacity for solar photovoltaic power generation (F7): This is one of the important indicators of the capacity scale in this field [46,47].

- Photovoltaic power consumption capacity (F8): This capacity is identified as the local acceptance level of solar photovoltaic power generation projects $[48,49]$.

- Export volume of photovoltaic products (F9): This reflects the demand situation of related foreign industries, which indirectly stimulates the development of the local photovoltaic industry [50].

\subsection{Firm Strategy, Structure, and Rivalry}

The determinants of firm strategy, structure, and rivalry include reasonable and effective development plans for photovoltaic power generation enterprises, interest rate risk, and grid-connected photovoltaic systems.

- Reasonable and effective development plans for photovoltaic power generation enterprises (F10): An enterprise should have a reasonable and effective renewable energy development plan and encourages consistent and stable strategic investment in photovoltaic power generation projects. The more effective the photovoltaic power generation enterprise's strategy, the more dynamic and competitive the industry will be. The strategy, management, and planning of photovoltaic companies play an irreplaceable role in analyzing the competitiveness of the industry [51,52].

- Interest rate risk (F11): This refers to the loss caused by future interest rate changes in the photovoltaic industry. The interest rate is the price of funds. It refers to the adjustment lever of the money market capital supply and demand relationship. In China, the interest rate is often subject to the management behavior of the central bank [53].

- Grid-connected photovoltaic system (F12): A grid-connected photovoltaic system is a trend in the development of the global photovoltaic industry. Combining grid planning with power plant planning and formulating relevant technical standards are more conducive to the promotion and implementation of the photovoltaic industry $[54,55]$. 


\subsection{Related and Support Industries}

The decisive factors for related and support industries include photovoltaic equipment manufacturing, photovoltaic power stations, and tax incentives.

- Photovoltaic equipment manufacturing (F13): This refers to the manufacturing industry provided by the photovoltaic industry and related electronic industries that benefit from the photovoltaic industry. These related and support industries will have an impact on the photovoltaic industry [56].

- $\quad$ Photovoltaic power station (F14): Micro-grids, grid energy storage, and smart grids must be developed to ensure the safety, stability, and reliability of photovoltaic power stations [57].

- Tax incentives (F15): The renewable energy industry policy adopted by the Chinese government provides tax incentives for photovoltaic power generation projects, including tax exemptions and tax reductions [58]. Renewable-energy-related enterprises enjoy tax incentives in terms of equipment depreciation.

\subsection{Government}

The decisive factors of government include policies issued by local governments, tax reduction and exemption, financial subsidy intensity, China's central government photovoltaic power generation target, and feed-in tariff $[59,60]$.

- Policies issued by local governments (F16): The photovoltaic industry also relies on local government policies that affect demand prospects. These policies have a clear banner color and accelerate the commercialization of the photovoltaic industry to a certain extent, such as via bidding policies and the renewable portfolio standard [61].

- Tax reduction and exemption (F17): The three major taxes affecting China's photovoltaic industry are value-added tax, customs duties, and corporate income tax. Among them, value-added tax and customs duties are exempted within the prescribed scope and corporate income tax rates vary according to region.

- Financial subsidy intensity (F18): The financial department arranges subsidies for special funds for renewable energy, including subsidies for grid power generation projects, independent power generation projects, photovoltaic technology industrialization demonstration projects, and photovoltaic power generation infrastructure construction.

- China's central government photovoltaic power generation target (F19): This target can formulate long-term or short-term plans according to the needs and feasibility of different regions in China to provide government commitment indicators for consumers and producers in the photovoltaic industry [40].

- Feed-in tariff (F20): This policy can provide a fixed long-term price guarantee for local photovoltaic power generation companies [61].

\subsection{Chance}

The determinants of chance include opportunities brought by the 531 Photovoltaic New Deal and the prospects of the photovoltaic industry.

- Opportunities brought by the 531 Photovoltaic New Deal (F21): This deal brings new opportunities to the photovoltaic industry. The photovoltaic industry can be market oriented, and the degree of dependence on government policies is reduced. It also brings heavy losses to some enterprises.

- Prospects of the photovoltaic industry (F22): Photovoltaic power generation shows promise in reducing environmental pressure, which is mainly reflected in the environmental capacity of the region and the environmental and social impacts related to the production and consumption of photovoltaic power generation. 


\section{Results}

\subsection{Hierarchical Structure}

To conduct an AHP, the hierarchical structure was created with the categories and subcategories that were clarified through the literature review (see Section 3). The goal of the analysis is at the top of the hierarchy: "Assessing the relative importance of the determinants of the photovoltaic industry." The categories (factor condition; demand condition; firm strategy, structure, and rivalry; related and support industries; government; and chance) come below, and the subcategories or determinants come under the categories. The hierarchical structure is shown in Figure 1.

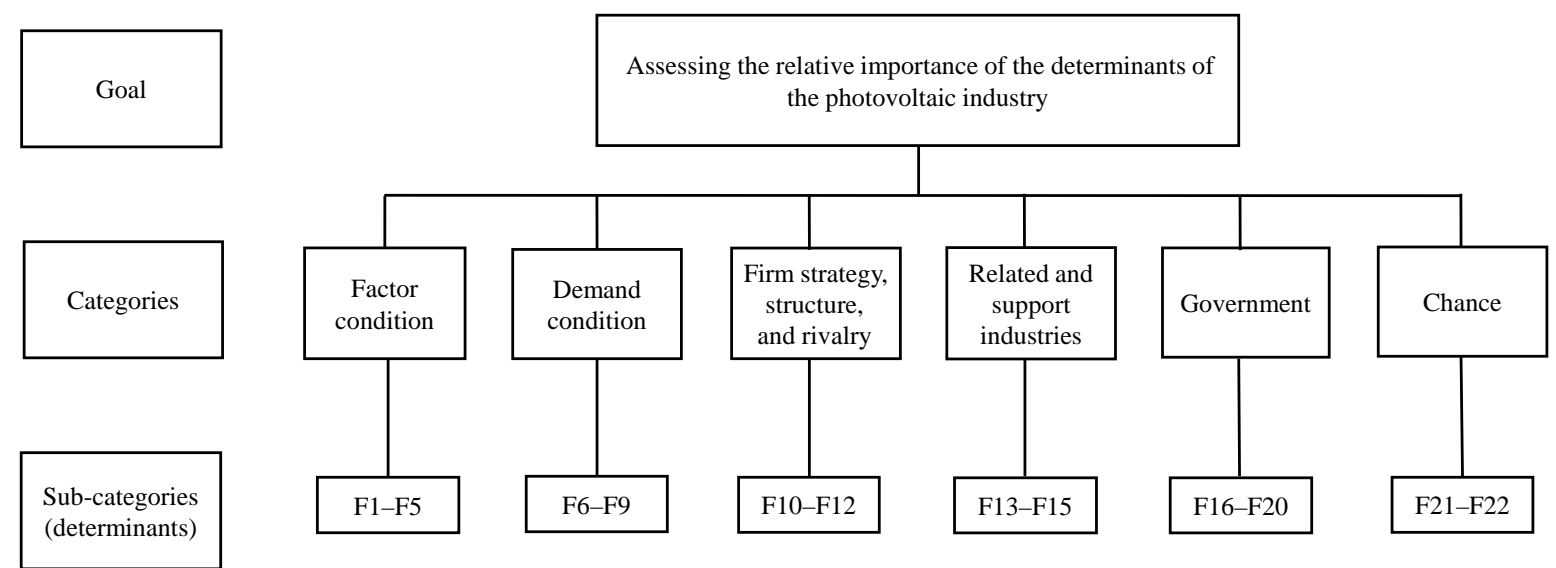

Figure 1. Hierarchical structure. See Table 5 for the definitions of F1-F22.

The respondents initially evaluated the relative importance of the six categories and then the importance of the determinants under each category. The authors calculated the relative importance of each category and determinant based on the respondents' evaluation results.

\subsection{Relative Importance of the Six Categories}

Comparing the six factors (categories), the factor condition was the most important determinant (51.9\%; Figure 2). Demand condition and firm strategy, structure, and rivalry were $23.6 \%$ and $8.9 \%$ important, respectively. Government and chance were $4.5 \%$ and $7.2 \%$ important, respectively, and related and support industries were rated as the least important determinants (3.9\%). The consensus rate was $99.0 \%$, indicating a high level of consensus among the respondents.

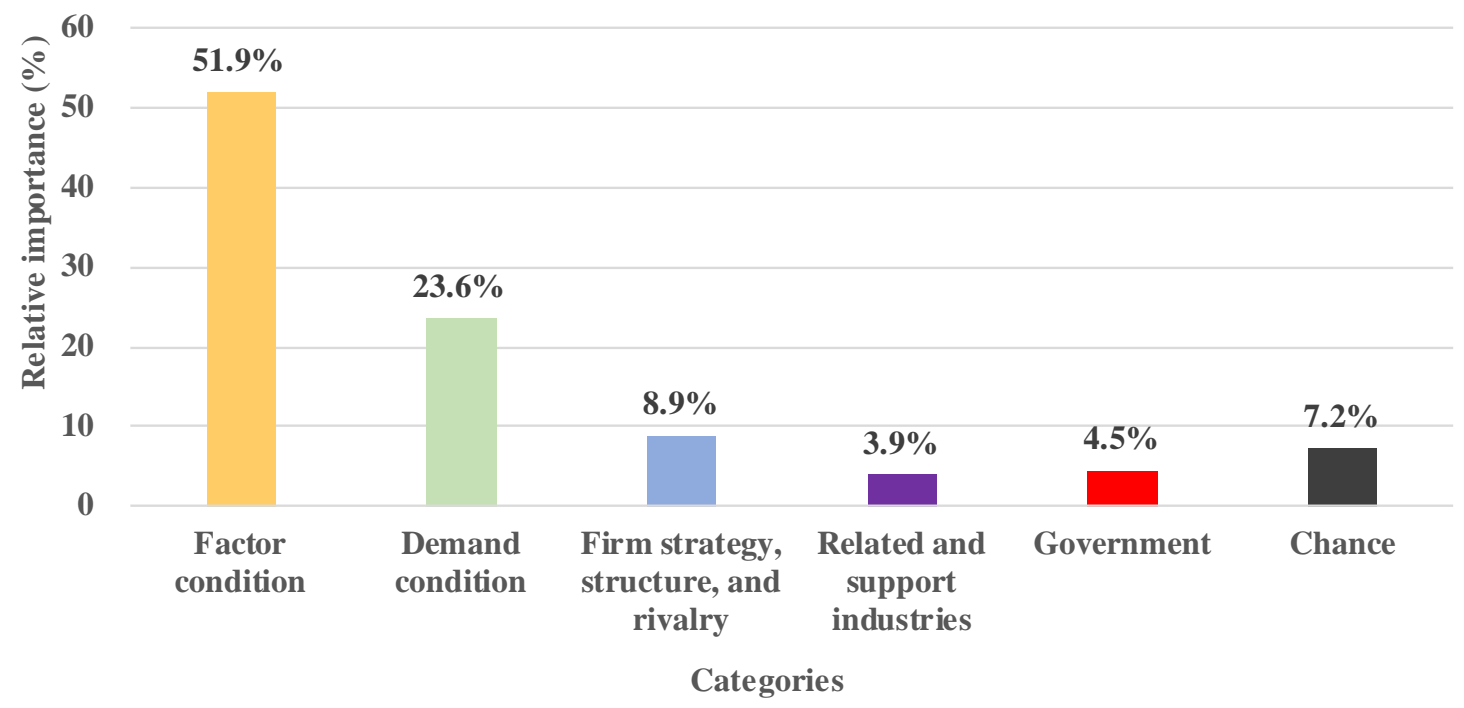

Figure 2. Relative importance of the six categories. 


\subsection{Relative Importance of Factor Condition Determinants}

The relative importance of factor condition determinants is shown in Figure 3. Natural resources were considered the most important determinant (52.5\%) of the competitiveness of China's photovoltaic industry. The development of the photovoltaic industry requires solar radiation, and regions with relatively abundant solar radiation resources have priority in the development of the photovoltaic industry. Mineral resources, labor costs, scientific research and technology, and acquiring land were $24.5 \%, 11.6 \%, 4.6 \%$, and $6.7 \%$ important, respectively. The consensus rate was $99.0 \%$.

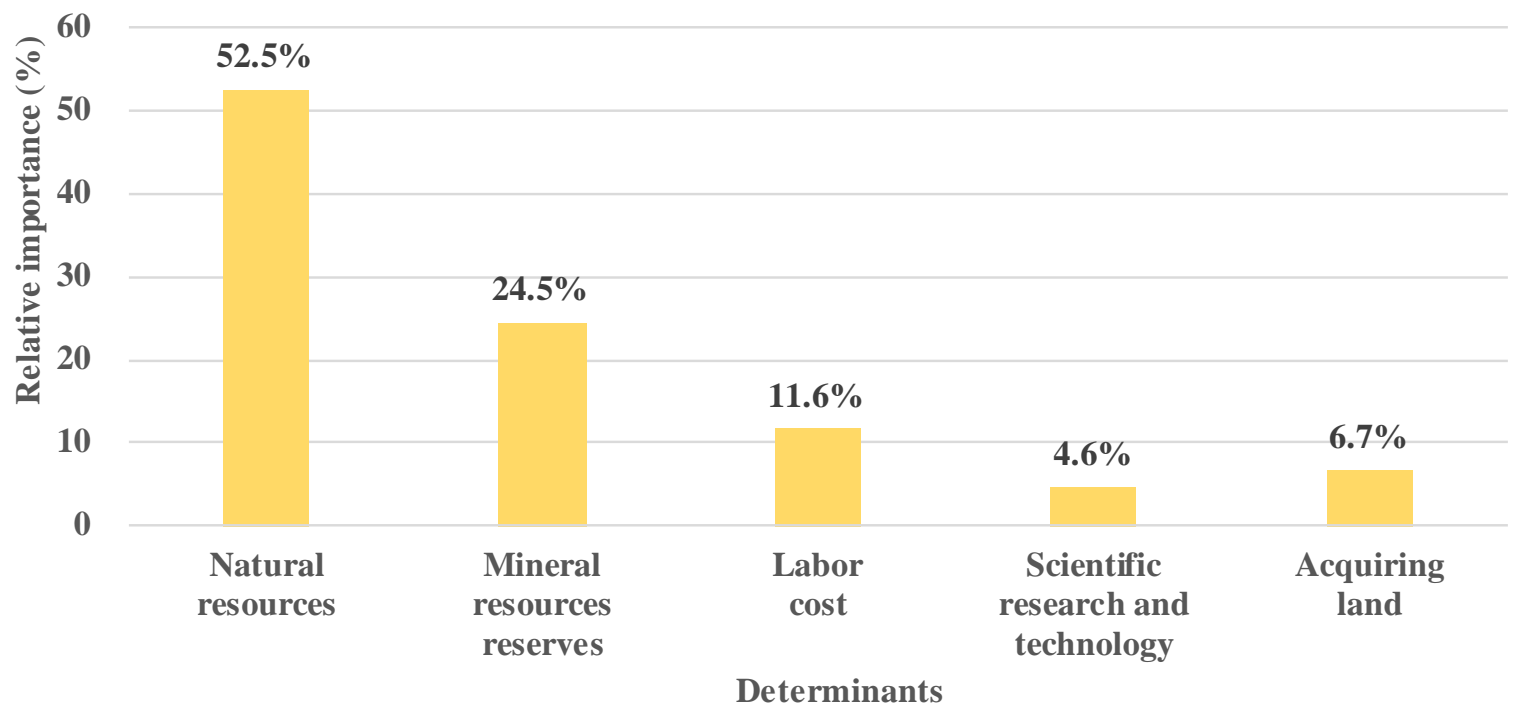

Figure 3. Relative importance of factor condition determinants.

\subsection{Relative Importance of Demand Condition Determinants}

The relative importance of the demand condition determinants is shown in Figure 4. Respondents believed that the energy supply gap was the most important determinant under the demand condition, with a weight of $59.7 \%$. This is mainly because the traditional energy supply industry cannot meet the growing economic demand, which stimulates and accelerates the development of the photovoltaic industry to a certain extent. The weights of the newly installed capacity for solar photovoltaic power generation, photovoltaic power consumption capacity, and export volume of photovoltaic products were $17.1 \%, 8.6 \%$, and $14.6 \%$, respectively. The consensus rate was $94.1 \%$.

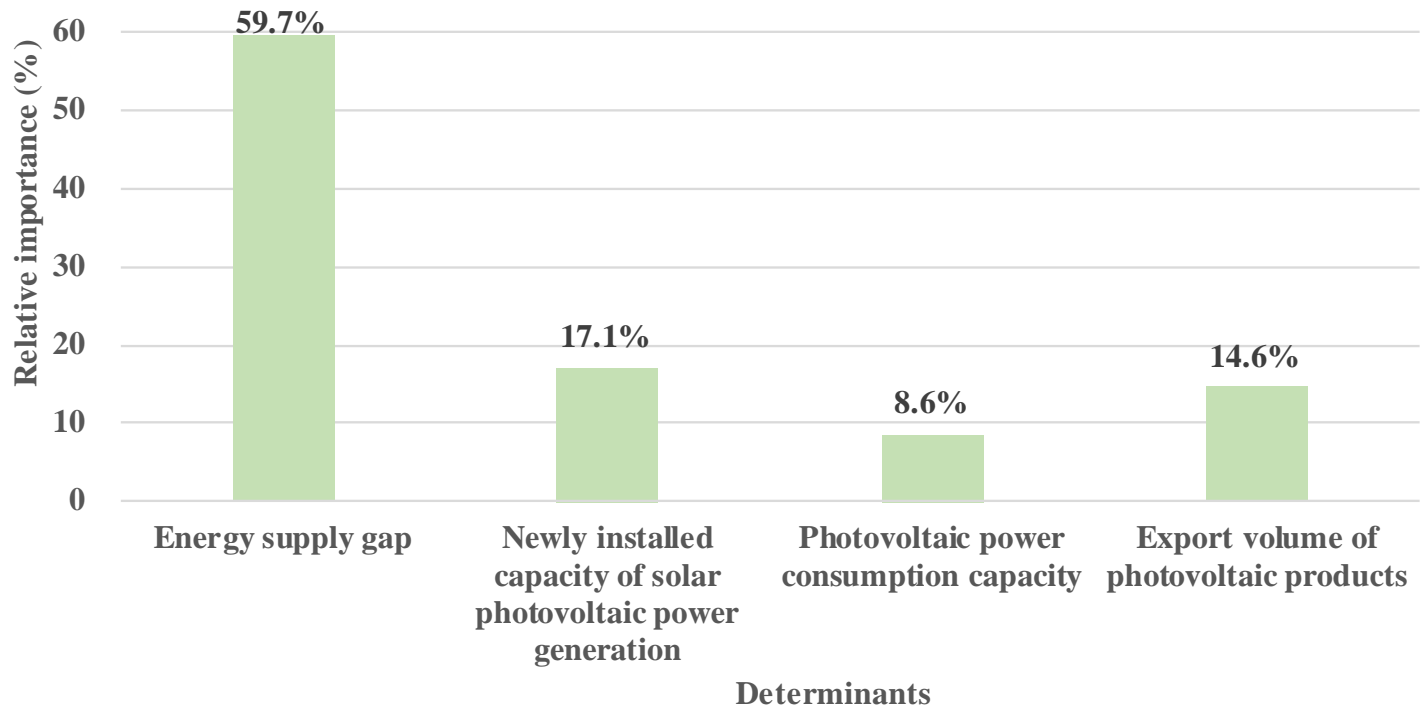

Figure 4. Relative importance of demand condition determinants. 


\subsection{Relative Importance of Firm Strategy, Structure, and Rivalry Determinants}

Figure 5 shows the relative importance of firm strategy, structure, and rivalry. Interest rate risk and grid-connected photovoltaic systems were relatively important, at 59.5\% and $25.9 \%$, respectively. The weight of reasonable and effective development plans for photovoltaic power generation enterprises was $14.7 \%$. The consensus rate was $94.4 \%$. Respondents generally believed that interest rate risk is the main determinant. The interest rate level of foreign markets and changes in monetary policy will indirectly affect the price of domestic currency and cause losses to the photovoltaic industry.

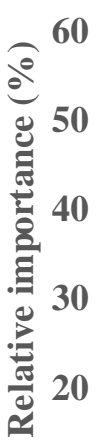

10

0
$59.5 \%$

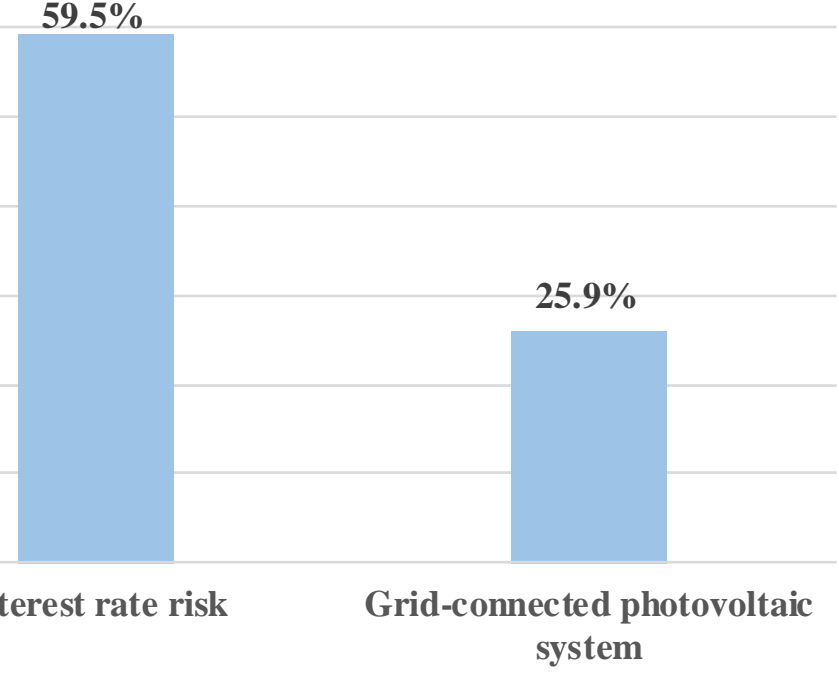

\section{Determinants}

Figure 5. Relative importance of the firm strategy, structure, and rivalry determinants.

\subsection{Relative Importance of Related and Support Industries Determinants}

The results of the relative importance of the related and support industries determinants (Figure 6) show that photovoltaic power stations and tax incentives were very important, at $58.8 \%$ and $27.8 \%$, respectively. Experts believed that the role of photovoltaic equipment manufacturing is not so important (13.4\%). The consensus rate was $95.7 \%$.
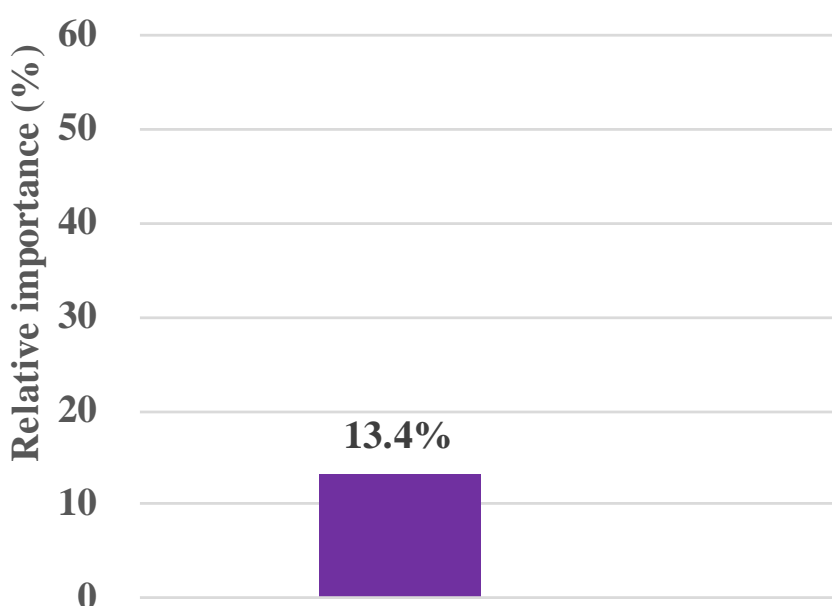

\section{$58.8 \%$}

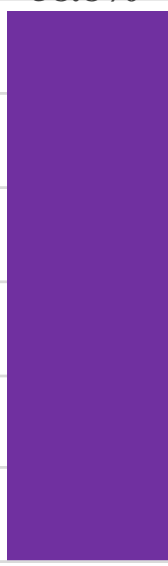

$27.8 \%$

Photovoltaic equipment

Photovoltaic power station

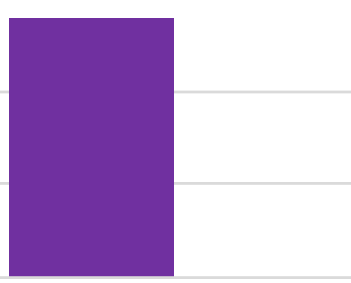

manufacturing

\section{Determinants}

Figure 6. Relative importance of the related and support industries determinants. 


\subsection{Relative Importance of Government Determinants}

Figure 7 shows the results of government determinants. In China's photovoltaic industry, policies issued by local governments were rated as the most important factor (57.2\%). Tax reduction and exemption was $19.8 \%$ important. Financial subsidy intensity, China's central government photovoltaic power generation target, and feed-in tariff account were less important, at $6.5 \%, 6.3 \%$, and $10.1 \%$, respectively. The consensus rate was $98.9 \%$.

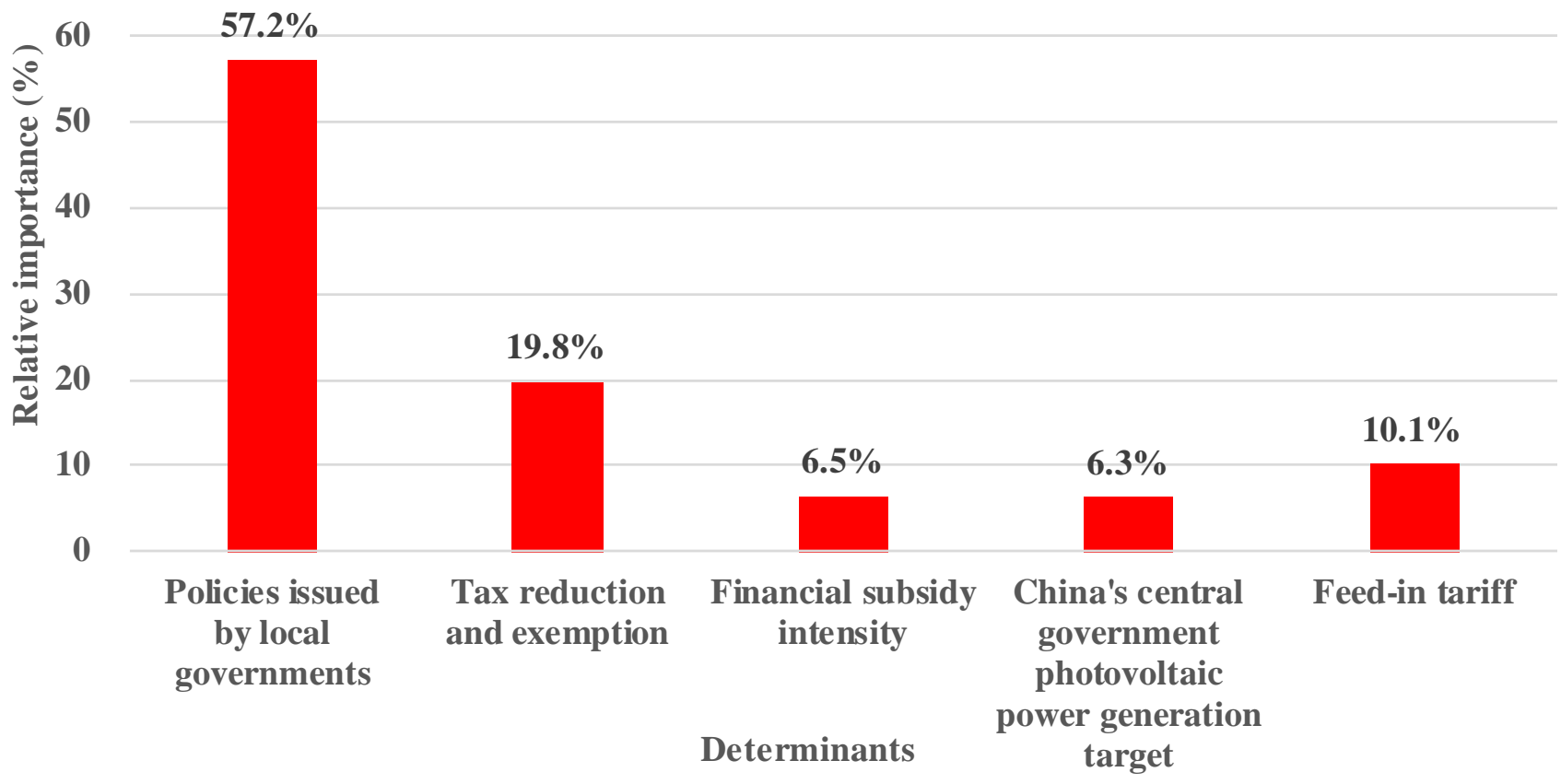

Figure 7. Relative importance of government determinants.

\subsection{Relative Importance of Chance Determinants}

Figure 8 shows the results of chance's determinants. Experts generally believed that the prospects of the photovoltaic industry are very important, with a weight of $86.0 \%$. However, opportunities brought by the 531 Photovoltaic New Deal had a relatively small impact on the industry, with a weight of $14.0 \%$. The consensus rate was $98.5 \%$.
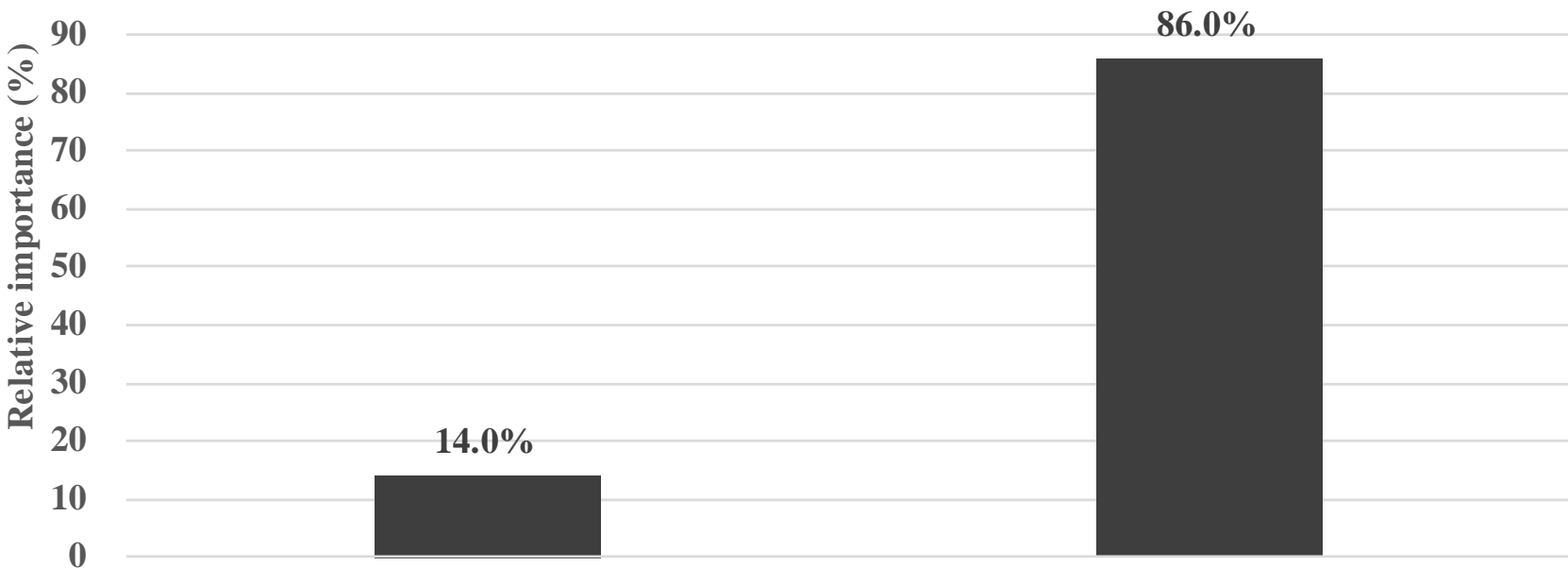

Opportunities brought by the 531 Photovoltaic Prospects of the photovoltaic industry New Deal

\section{Determinants}

Figure 8. Relative importance of the chance determinants. 


\subsection{Relative Importance of all Determinants}

We multiplied the weight of each subcategory $\mu_{s u b}$ by the weight of the category $\mu_{c}$ to which the subcategory belongs to calculate the relative importance of each subcategory $I_{\text {sub }}$ by Equation (8):

$$
I_{s u b}=u_{s u b} \times u_{c}
$$

For example, the weight of natural resources (52.5\%) is multiplied by the weight of the factor condition (51.9\%), which makes the relative importance of natural resources in all determinants $27.25 \%$.

Figure 9 shows the final results of all subcategories. Natural resources had the highest weight among all determinants $(27.25 \%)$, followed by the energy supply gap (14.03\%), mineral resources reserves $(12.72 \%)$, prospects of the photovoltaic industry $(6.19 \%)$, labor cost $(6.02 \%)$, interest rate risk (5.36\%), newly installed capacity for solar photovoltaic power generation $(4.02 \%)$, acquiring land $(3.48 \%)$, and export volume of photovoltaic products $(3.43 \%)$. This result highlights the determinants important for improving the development of China's photovoltaic industry and the priorities among them.

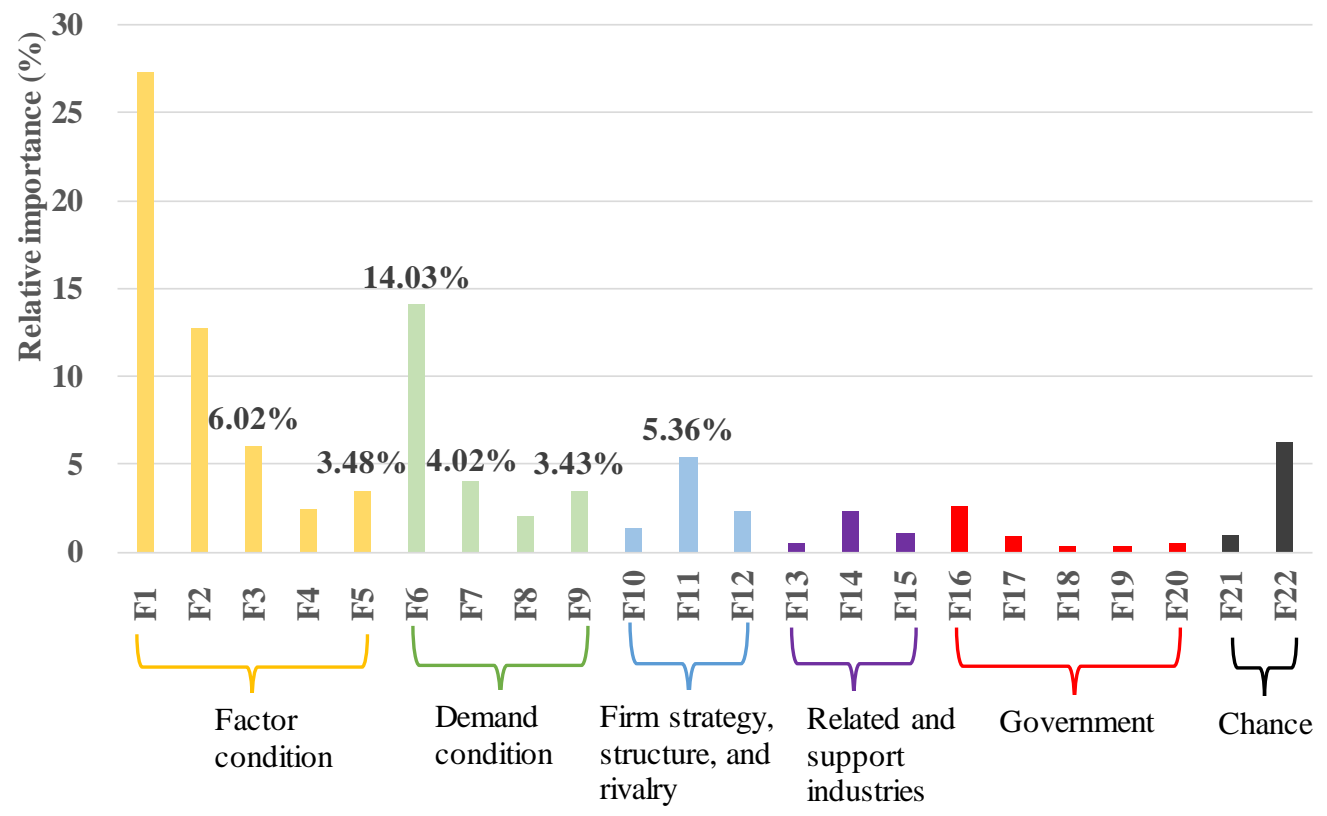

Figure 9. Relative importance of all determinants (see Table 5 for the definitions of F1-F22).

\section{Discussion}

This section presents a detailed discussion of the key determinants of the competitiveness of China's photovoltaic industry. Although natural resources, mineral resources reserves, and prospects of the photovoltaic industry are important factors, they are not discussed here. Regions with good resource endowments have relatively greater potential for development. Natural resources and mineral resources reserves are necessary conditions for the development of the photovoltaic industry; their importance is unquestionable; so it will not be discussed. This questionnaire survey was conducted only among experts in the photovoltaic industry. Considering the singularity of the questionnaire field and the commonality among experts in the same industry, the relative importance of prospects of the photovoltaic industry cannot represent the entire prospects of the photovoltaic power generation industry in China; it only represents the views of experts in the photovoltaic industry on its prospects. Therefore, the importance of prospects of the photovoltaic industry is not the subject of discussion here. The discussion below is conducted in the following order: energy supply gap (14.03\%); interest rate risk (5.36\%); labor cost $(6.02 \%)$; acquiring land (3.48\%); newly installed capacity for solar photovoltaic power generation (4.02\%); and the export volume of photovoltaic products (3.43\%). 


\subsection{Energy Supply Gap and the Development of China's Photovoltaic Industry}

According to the China Electric Power Yearbook [62], solar energy generation has increased significantly more than other types of energy generation (Figure 10), of which the largest increase, in 2017, was $75.29 \%$. The growth rate of thermal power generation was negative $(-1.68 \%)$ in 2015 . Although the growth rate of thermal power generation was positive in 2016 and 2017, it was relatively small. This indicates that the Chinese government vigorously developed wind and solar power generation, among which the development of solar power generation was the most significant.

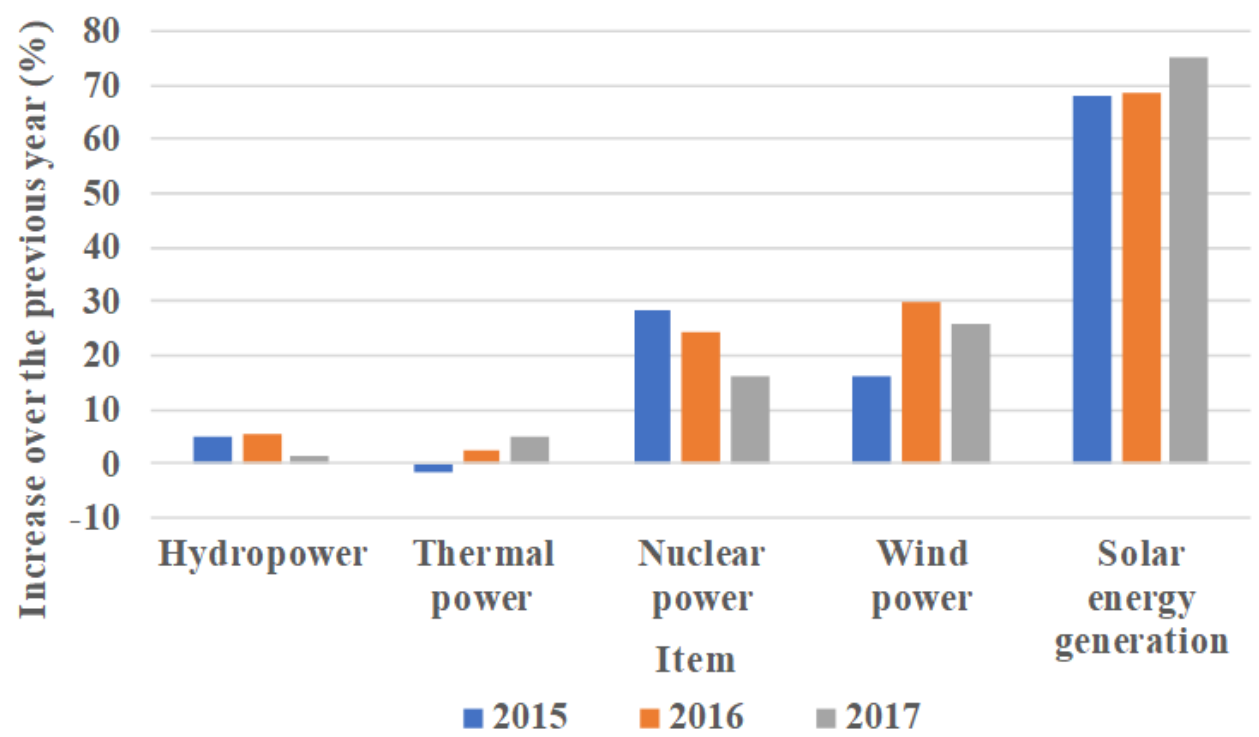

Figure 10. Power generation growth rate in China [62].

\subsection{Interest Rate Risk and the Development of China's Photovoltaic Industry}

Interest rate risk will have an impact on the future photovoltaic industry. In China, interest rates play a role in regulating the supply and demand of money in the money market $[53,63]$. Considering that the photovoltaic industry requires long-term investment and returns, decision makers in this industry will be discouraged in regions with relatively high interest rate risk for financial institutions [64]. Interest rate risk will not only affect the future returns of photovoltaic projects but also increase the initial financing costs. From a macroeconomic perspective, to accelerate the development of China's photovoltaic industry, it is necessary to maintain a stable currency environment.

\subsection{Labor Cost and Acquiring Land}

The level of labor cost is an important determinant of the competitiveness of China's photovoltaic industry (Figure 9). According to the China Industrial Statistics Yearbook [65], the average number of workers required for photovoltaic equipment and component manufacturing and solar power generation was 31.7 million in 2017 and 28.79 million in 2020. The total investment income of photovoltaic equipment and component manufacturing and solar power generation was 1.15 billion yuan in 2017 and 2.624 billion yuan in 2020 . The ratio of the average number of workers to the total investment income was approximately 3 million people/billion yuan in 2017 and 1 million people/billion yuan in 2020. Hence, the decrease in the total average number of workers was accompanied by an increase in total investment income. In other words, a reduction in labor costs will help increase the investment income of the photovoltaic industry. According to the opinions of the 20 experts in the questionnaire, the ways of reducing labor costs can be roughly divided into three categories: technological innovation, power grid transformation, and improvement of equipment manufacturing capacity. Other measures may also be used to reduce labor costs in the photovoltaic industry. 
Although the relative importance of acquiring land was quite low, at only $3.48 \%$, acquiring land is a slow and unclear process in China [66]. This mainly refers to unclear land ownership and restrictions on land purchase. Therefore, to develop China's photovoltaic industry, national, provincial, and local authorities need to coordinate with each other and set up a special department to establish a fast track for purchasing land for use in the photovoltaic industry. This will not only attract potential investors but also provide a basic guarantee for the development of the photovoltaic field.

\subsection{Newly Installed Capacity for Solar Photovoltaic Power Generation}

Solar power generation includes photovoltaic, photochemical, light induction, and photobiological power generation methods. Thus, photovoltaic power generation is only one of them. According to the latest data released by the China Electric Power Yearbook [62] and the Qianzhan Industry Research Institute [67], the newly installed capacity for photovoltaic power generation in 2017 was $53.06 \mathrm{GW}$ and the newly installed capacity for solar power generation was $53.41 \mathrm{GW}$ in 2017. In the newly installed capacity for solar power generation, photovoltaic power generation accounted for $99 \%$, which indicates that $99 \%$ of the newly installed capacity for solar power generation in 2017 came from photovoltaic power generation. Thus, the newly installed capacity for photovoltaic power generation in 2017 can be considered equal to the newly installed capacity for solar power generation. The value of the newly installed capacity for solar power generation by region in 2017, provided by the China Electric Power Yearbook [62], was used to calculate the proportion of newly installed capacity for solar power generation in each province (equal to the proportion of newly installed capacity for photovoltaic power generation) in Figure 11. Figure 11 indicates that the proportion is lower in the west and higher in the east. The pink area represents more than $5 \%$ of the proportion of newly installed capacity for photovoltaic power generation, and these are mainly concentrated in these areas. Electricity consumption in these areas has increased rapidly over the years, and the demand for energy is relatively high [68]. Traditional energy supplies cannot meet the increasing energy demand. Therefore, leaders of the photovoltaic industry and photovoltaic policymakers should prioritize the development of the photovoltaic industry in the central and coastal areas. This will not only solve the problems caused by insufficient local traditional energy supply but also improve the exports of photovoltaic products and increase local economic sources.

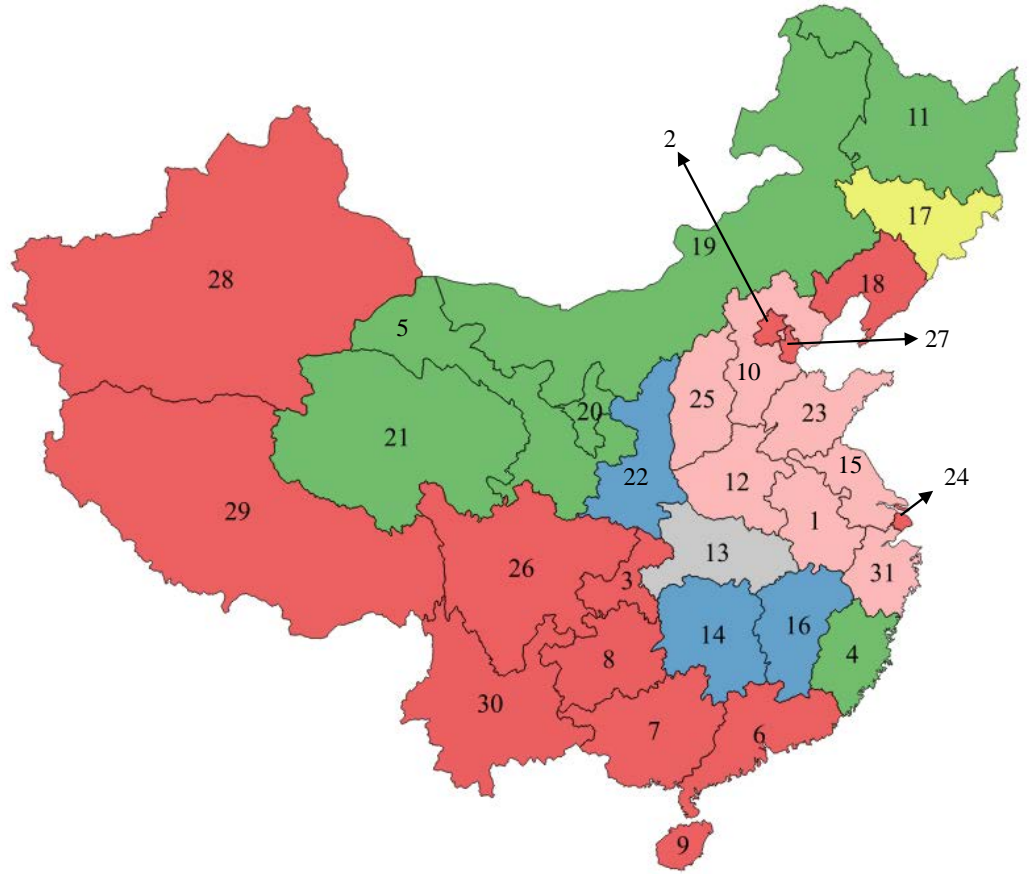

No. Province

1. Anhui

2. Beijing

3. Chongqing

4. Fujian

5. Gansu

6. Guangdong

7. Guangxi

8. Guizhou

9. Hainan

10. Hebei

11. Heilongjiang

12. Henan

13. Hubei

14. Hunan

15. Jiangsu

16. Jiangxi
No. Province

17. Jilin

18. Liaoning

19. Inner Mongolia

20. Ningxia

21. Qinghai

22. Shaanxi

23. Shandong

24. Shanghai

25. Shanxi

26. Sichuan

27. Tianjin

28. Xinjiang

29. Xizang

30. Yunnan

31. Zhejiang

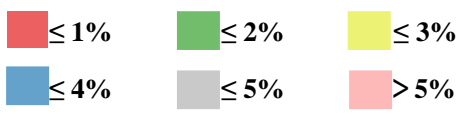

Figure 11. Proportion of newly installed capacity for photovoltaic power generation by region in mainland China in 2017. 


\subsection{Export Volume of Photovoltaic Products}

According to the latest statistics from the China Photovoltaic Industry Association $[69,70]$, in 2019, China's photovoltaic product exports were USD 20.78 billion. The newly installed capacity of overseas photovoltaics was $85 \mathrm{GW}$, an annual increase of $37.7 \%$. This shows that the demand for photovoltaic products in overseas markets has increased. As shown in Figure 12, the export volumes of silicon wafers, solar cells, and photovoltaic modules were $27.3 \mathrm{GW}, 10.4 \mathrm{GW}$, and $66.6 \mathrm{GW}$ and the export values were USD 2 billion, USD 1.47 billion, and USD 17.31 billion, respectively. The China Photovoltaic Industry Association [69] and the Qianzhan Industry Research Institute [67] have identified the main reasons for the increase in the export volume of photovoltaic products. As the capital, technology, cost, and other aspects continue to increase, some overseas photovoltaic companies are slowly withdrawing from the market under the dual pressures of cost increase and profit reduction. This has led to a further concentration of foreign photovoltaic markets in the Chinese market. The photovoltaic markets of many countries, such as the Netherlands, Vietnam, Japan, India, and Australia, choose to import silicon wafers, solar cells, and photovoltaic modules directly from China.

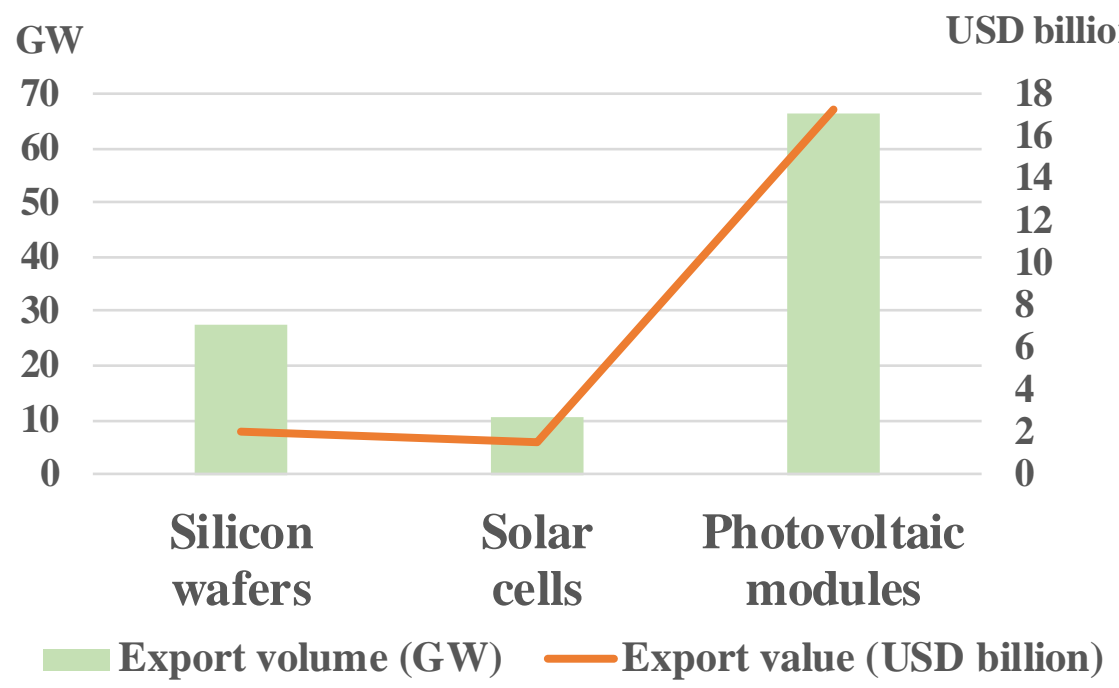

Figure 12. Export volume (GW) and export value (USD billion) of China's main photovoltaic products in 2019 [69].

\section{Conclusions}

This study took photovoltaic companies in Southwest China, Beijing-Tianjin-Hebei, Yangtze River Delta, Pearl River Delta, and Northwest China as research subjects and used the diamond model and the AHP to assess the relative importance of the determinants of the competitiveness of China's photovoltaic industry. In addition to the determinants of the factor condition (e.g., natural resources and mineral resource reserves), the determinants of the demand condition and firm strategy, structure, and rivalry have also proven to be of relative importance.

The dual pressure of economic growth and environmental improvement drives the increase in the energy supply gap, which will invisibly provide a new environment for China's photovoltaic industry. Therefore, we can develop this industry by maintaining a stable monetary environment, reducing labor costs, improving photovoltaic manufacturing power, opening green channels for land purchase, and increasing the development of the overseas photovoltaic market. Special attention should be paid to the central region and coastal areas, which have great potential for the development of this industry. As argued by Cheong et al. [68], urban diversification and differences in economic activity in these areas lead to the requirement of more energy supply. 
Compared with the relative importance of the government, this study found that the relative importance of firm strategy, structure, and rivalry was greater. This shows that we should vigorously encourage the development of enterprises and urge them to improve the development of the photovoltaic industry through innovation and competition. However, this study has two limitations. First, the development of the photovoltaic industry in different provinces of China is not uniform. This study is an overall assessment of the relative importance of the determinants of China's photovoltaic industry. The results are not necessarily applicable to all provinces. The development of different provinces needs further comparative analysis. Second, this research was conducted in China. Therefore, it is necessary to explore what will happen in other countries. Nevertheless, it should be noted that the same method can be applied in other countries as well.

Supplementary Materials: The following are available online at https:/ /www.mdpi.com/article/10.3390/ en14206600/s1, Table S1: The 14th Five-Year Plan of newly increased photovoltaic scale; Figure S1: Relative importance of determinants of solar photovoltaic industry in China.

Author Contributions: Conceptualization, methodology, formal analysis, investigation, resources, data curation, and visualization, T.Z.; software and validation, T.Z. and K.M.; writing- original draft preparation, T.Z.; writing-review and editing, T.Z., K.M. and K.N.; supervision, K.M. and K.N.; project administration, T.Z., K.M. and K.N.; funding acquisition, K.M. and K.N. All authors have read and agreed to the published version of the manuscript.

Funding: This study was funded by the Integrated Research Program for Advancing Climate Models (grant number JPMXD0717935715) at the Ministry of Education, Culture, Sports, Science and Technology, Japan, and JSPS KAKENHI (grant numbers JP18K11800, JP19H04340, JP20K12209, and JP21H03673).

Institutional Review Board Statement: Not applicable.

Informed Consent Statement: Not applicable.

Data Availability Statement: The data presented in this study are available on request from the corresponding author.

Acknowledgments: The authors sincerely thank the editor and anonymous reviewers for their insightful comments and suggestions. Furthermore, the authors would like to thank all 24 interviewees who took the time to participate in the questionnaire survey.

Conflicts of Interest: The authors declare no conflict of interest.

\section{References}

1. The Central People's Government of the People's Republic of China. Available online: http://www.gov.cn/xinwen/2021-03/13 / content_5592681.htm (accessed on 23 August 2021).

2. International Energy Agency. World Energy Outlook 2019. Available online: www.iea.org/weo (accessed on 23 August 2021).

3. Tsai, P.H.; Chen, C.J.; Yang, H.C. Using Porter's Diamond Model to Assess the Competitiveness of Taiwan's Solar Photovoltaic Industry. Sage Open 2021, 11. [CrossRef]

4. Luo, Z.; He, J.; Hu, S. Driving force model to evaluate China's photovoltaic industry: Historical and future trends. J. Clean. Prod. 2021, 311, 127637. [CrossRef]

5. Zhao, X.; Wei, W.; Ling, W. A dynamic analysis of research and development incentive on China's photovoltaic industry based on system dynamics model. Energy 2021, 233, 121141. [CrossRef]

6. Shao, X.; Fang, T. Performance analysis of government subsidies for photovoltaic industry: Based on spatial econometric model. Energy Strategy Rev. 2021, 34, 100631. [CrossRef]

7. Xu, M.; Xie, P.; Xie, B.C. Study of China's optimal solar photovoltaic power development path to 2050. Resour. Policy 2020, 65, 101541. [CrossRef]

8. Dögl, C.; Holtbrügge, D.; Schuster, T. Competitive advantage of German renewable energy firms in India and China An empirical study based on Porter's diamond. Int. J. Emerg. Mark. 2012, 7, 191-214. [CrossRef]

9. Fang, K.; Zhou, Y.; Wang, S.; Ye, R.; Guo, S. Assessing national renewable energy competitiveness of the G20: A revised Porter's Diamond Model. Renew. Sustain. Energy Rev. 2018, 93, 719-731. [CrossRef]

10. Li, X. Research on International Competitiveness of China PV Industry. Master's Thesis, Hainan University, Haikou, China, 2016.

11. Long, J. The Research on the International Competitiveness of Solar Energy Photovoltaic Industry in China. Master's Thesis, Beijing Linye University, Beijing, China, 2013. 
12. Jing, S. Research on the international trade competitiveness of China's solar photovoltaic industry. Prices Mon. 2017, 12, 32-36. [CrossRef]

13. Ji, S. Evaluation and Improvement of China's Photovoltaic Industry Competitiveness Based on the Modified Diamond Model-Comparative Analysis of China's Photovoltaic Industry and Some Countries. Master's Thesis, Northwest University, Xi'an, China, 2014.

14. Chen, X.Y. Researching on the International Competitiveness of the Solar Industry. Ph.D. Thesis, Nankai University, Tianjin, China, 2010.

15. Zhao, Z.Y.; Zhang, S.Y.; Zuo, J. A critical analysis of the photovoltaic power industry in China-From diamond model to gear model. Renew. Sustain. Energy Rev. 2011, 15, 4963-4971. [CrossRef]

16. Painuly, J.P. Barriers to renewable energy penetration: A framework for analysis. Renew. Energy 2001, 24, 73-89. [CrossRef]

17. Chung, T.W. A Study on Logistics Cluster Competitiveness among Asia Main Countries using the Porter's Diamond Model. Asian J. Shipp. Logist. 2016, 32, 257-264. [CrossRef]

18. Porter, M.E. The Competitive Advantage of Nations. Harv. Bus. Rev. 1990, 68, 73-93.

19. Kharub, M.; Sharma, R. Comparative analyses of competitive advantage using Porter diamond model (the case of MSMEs in Himachal Pradesh). Compet. Rev. 2017, 27, 132-160. [CrossRef]

20. Stone, H.B.J.; Ranchhod, A. Competitive advantage of a nation in the global arena: A quantitative advancement to Porter's diamond applied to the UK, USA and BRIC nations. Strateg. Chang. 2006, 15, 283-294. [CrossRef]

21. Wu, Y.; Xiao, X.; Song, Z. Competitiveness analysis of coal industry in China: A diamond model study. Resour. Policy 2017, 52, 39-53. [CrossRef]

22. Zhao, Z.Y.; Hu, J.; Zuo, J. Performance of wind power industry development in China: A DiamondModel study. Renew. Energy 2009, 34, 2883-2891. [CrossRef]

23. Esen, S.; Uyar, H. Examining the competitive structure of Turkish tourism industry in comparison with diamond model. Procedia Soc. Behav. Sci. 2012, 62, 620-627. [CrossRef]

24. Bakan, İ.; Fatma Doğan, İ. Competitiveness of the industries based on the Porter's diamond model: An empirical study. Int. J. Res. Rev. Appl. Sci. 2012, 11, 441-455.

25. Porter, M.E. The Adam Smith address: Location, clusters, and the "new" microeconomics of competition. Bus. Econ. 1998, 33, 7-13.

26. Saaty, T.L. How to Make a Decision: The Analytic Hierarchy Process. Inst. Manag. Sci. 1994, 24, 19-43. [CrossRef]

27. Sipahi, S.; Timor, M. The analytic hierarchy process and analytic network process: An overview of applications. Manag. Decis. 2010, 48, 775-808. [CrossRef]

28. Ghimire, L.P.; Kim, Y. An analysis on barriers to renewable energy development in the context of Nepal using AHP. Renew. Energy 2018, 129, 446-456. [CrossRef]

29. Heo, E.; Kim, J.; Boo, K.J. Analysis of the assessment factors for renewable energy dissemination program evaluation using fuzzy AHP. Renew. Sustain. Energy Rev. 2010, 14, 2214-2220. [CrossRef]

30. Mastrocinque, E.; Ramírez, F.J.; Honrubia-Escribano, A.; Pham, D.T. An AHP-based multi-criteria model for sustainable supply chain development in the renewable energy sector. Expert Syst. Appl. 2020, 150, 113321. [CrossRef]

31. Tsai, S.; Rawson, D.M.; Zhang, T. Development of cryopreservation protocols for early stage zebrafish (Danio rerio) ovarian follicles using controlled slow cooling. Theriogenology 2009, 71, 1226-1233. [CrossRef]

32. Keeley, A.R.; Matsumoto, K. Relative significance of determinants of foreign direct investment in wind and solar energy in developing countries-AHP analysis. Energy Policy 2018, 123, 337-348. [CrossRef]

33. Luthra, S.; Kumar, S.; Garg, D.; Haleem, A. Barriers to renewable/sustainable energy technologies adoption: Indian perspective. Renew. Sustain. Energy Rev. 2015, 41, 762-776. [CrossRef]

34. Goepel, K.D. Implementing the analytic hierarchy process as a standard method for multi-criteria decision making in corporate enterprises-A new AHP excel template with multiple inputs. Proc. Int. Symp. Anal. Hierarchy Process 2013, 2, 1-10. [CrossRef]

35. The AHP Excel Template. Available online: https://bpmsg.com/new-ahp-excel-template-with-multiple-inputs/ (accessed on 23 August 2021).

36. Global Horizontal Irradiation, China. 2019. Available online: https://solargis2-web-assets.s3.eu-west-1.amazonaws.com/public/ flyers/36dd721927/Solargis_maps-2019-05-17_GHI-China-web.pdf (accessed on 23 August 2021).

37. YuJie, L.; Tao, P. Spatial Simulation of China's Land Surface Solar Radiation Resources. J. Nat. Resour. 2012, 27, $1392-1403$.

38. Chen, W.; Hong, J.; Yuan, X.; Liu, J. Environmental impact assessment of monocrystalline silicon solar photovoltaic cell production: A case study in China. J. Clean. Prod. 2016, 112, 1025-1032. [CrossRef]

39. Lam, L.T.; Branstetter, L.; Azevedo, I.L. A sunny future: Expert elicitation of China's solar photovoltaic technologies. Environ. Res. Lett. 2018, 13, 34038. [CrossRef]

40. Shubbak, M.H. The technological system of production and innovation: The case of photovoltaic technology in China. Res. Policy 2019, 48, 993-1015. [CrossRef]

41. Ji, J.; Tang, H.; Jin, P. Economic potential to develop concentrating solar power in China: A provincial assessment. Renew. Sustain. Energy Rev. 2019, 114, 109279. [CrossRef]

42. ShaoTing, Z. Research on the Reform of Rural Collective Land Property Right System from the Perspective of State Control. Ph.D. Thesis, Shanxi University, Taiyuan, China, 2018.

43. Huang, M.; He, Y.; Cen, H. Predictive analysis on electric-power supply and demand in China. Renew. Energy 2007, 32, 1165-1174. [CrossRef] 
44. Wang, Y.; Gu, A.; Zhang, A. Recent development of energy supply and demand in China, and energy sector prospects through 2030. Energy Policy 2011, 39, 6745-6759. [CrossRef]

45. Sheng, Y.; Shi, X.; Zhang, D. Economic growth, regional disparities and energy demand in China. Energy Policy 2014, 71, 31-39. [CrossRef]

46. National Energy Board. China's photovoltaic power generation construction and operation in the first quarter of 2019. Sol. Energy 2019, 6, 79 .

47. News, C.P. China's newly installed photovoltaic power generation capacity ranks first in the world for 5 consecutive years. Hydropower Stn. Des. 2018, 34, 104.

48. Yuan, X.; Zuo, J.; Ma, C. Social acceptance of solar energy technologies in China-End users' perspective. Energy Policy 2011, 39, 1031-1036. [CrossRef]

49. Heras-Saizarbitoria, I.; Cilleruelo, E.; Zamanillo, I. Public acceptance of renewables and the media: An analysis of the Spanish PV solar experience. Renew. Sustain. Energy Rev. 2011, 15, 4685-4696. [CrossRef]

50. Zhu, X.; He, C.; Gu, Z. How do local policies and trade barriers reshape the export of Chinese photovoltaic products? J. Clean. Prod. 2021, 278, 123995. [CrossRef]

51. Zhang, P.; Sun, M.; Zhang, X.; Gao, C. Who are leading the change? The impact of China's leading PV enterprises: A complex network analysis. Appl. Energy 2017, 207, 477-493. [CrossRef]

52. Sun, M.; Zhang, P.; Gao, C.; Ji, J.; Ampimah, B.C. Study on the mutual influence between enterprises: A complex network perspective of China's PV enterprises. J. Renew. Sustain. Energy 2016, 8, 063502. [CrossRef]

53. He, D.; Wang, H.; Yu, X. Interest rate determination in china: Past, present, and future. Int. J. Cent. Bank. 2015, 11, 255-277. [CrossRef]

54. Zou, X.; Li, B.; Zhai, Y.; Liu, H. Performance Monitoring and test System for Grid-Connected Photovoltaic Systems. In Proceedings of the 2012 Asia-Pacific Power and Energy Engineering Conference, Shanghai, China, 27-29 March 2012; pp. 1-4.

55. TingHui, Z.; MingChen, X.; BeiBei, W.; Kazuto, Y. System Dynamics Simulation of Shared Value of Distributed Photovoltaics and Its Impact on Distribution Network. Autom. Electr. Power Syst. 2021, 45, 35-44.

56. Goodrich, A.C.; Powell, D.M.; James, T.L.; Woodhouse, M.; Buonassisi, T. Assessing the drivers of regional trends in solar photovoltaic manufacturing. Energy Environ. Sci. 2013, 6, 2811-2821. [CrossRef]

57. Li, X. A Review on Energy Management, Operation Control and Application Methods for Grid Battery Energy Storage Systems CSEE J. Power Energy Syst. 2015, 1, 1-15. [CrossRef]

58. Beyer, S. Environmental Law and Policy in the People's Republic of China. Chin. J. Int. Law 2006, 5, 185-211. [CrossRef]

59. Bayaliyev, A.; Kalloz, J.; Robinson, M. China's Solar Policy: Subsidies, Manufacturing Overcapacity \& Opportunities. Available online: https: / / citeseerx.ist.psu.edu/viewdoc/download?doi=10.1.1.226.1981\&rep=rep1\&type=pdf (accessed on 20 June 2012).

60. Corwin, S.; Johnson, T.L. The role of local governments in the development of China's solar photovoltaic industry. Energy Policy 2019, 130, 283-293. [CrossRef]

61. Zhang, S.; He, Y. Analysis on the development and policy of solar PV power in China. Renew. Sustain. Energy Rev. 2013, 21, 393-401. [CrossRef]

62. China Electric Power Yearbook. Available online: https://data.cnki.net/trade/Yearbook/Single/N2019060101?z=Z025 (accessed on 13 August 2021).

63. Qingjun, J. Evolution of China's Monetary Policy Theory and Practice Since Reform and Opening up. Ph.D. Thesis, Fudan University, Shanghai, China, 2004.

64. Lardy, N.; Feng, G. Financial Reform Policies for Rebalancing Economic Growth. China Financ. Rev. 2013, 2, 18-38.

65. China Industrial Statistical Yearbook. Available online: https://data.cnki.net/yearbook/Single/N2021020054 (accessed on 13 August 2021).

66. Wei, X. Analysis On the System of "Collective Ownership of Rural Property". Ph.D. Thesis, China University of Political Science and Law, Beijing, China, 2020.

67. The Qianzhan Industry Research Institute. Available online: http://www.aikosolar.com/news/84.html (accessed on 13 August 2021).

68. Cheong, T.S.; Li, V.J.; Shi, X. Regional disparity and convergence of electricity consumption in China: A distribution dynamics approach. China Econ. Rev. 2019, 58, 101154. [CrossRef]

69. China Photovoltaic Industry Association. Available online: https://bg.qianzhan.com/trends/detail/506/200908-da3e9ade.html (accessed on 13 August 2021).

70. Hua, J.; Yanmei, J.; Xing, Y.; Yanzheng, Q.; Jiatong, L.; Peng, H. Review of China's PV Industry in 2019 and Prospect in 2020. Sol. Energy 2020, 3, 14-23. 